\title{
THE USE OF CALCOFLUOR WHITE FOR THE DETECTION OF FUNGI WHICH CAUSE SUBCUTANEOUS AND SYSTEMIC MYCOSES
}

\author{
El uso de blanco de calcofluor para la detección de los hongos causantes \\ de micosis subcutáneas y sistémicas
}

\begin{abstract}
Ramos, L., Borghi, A., Ramadan,S., Lopez,C. Centro de Referencia de Micología (CEREMIC). Facultad de Ciencias Bioquímicas y Farmaceúticas de la Universidad Nacional de Rosario. Suipacha 531. Rosario.(2000). Argentina.

Clara Eder López-Olivé 1469- Rosario (2000)- Argentina.

Phone/Fax: 54-41-307624. E-mail: lopez@cidoc.edu.ar
\end{abstract}

Palabras clave: Blanco de calcofluor, fluorescencia, técnica, micosis

Key words: Calcofluor white, fluoresence, technique, mycoses

\section{RESUMEN}

Esta técnica facilita la observación microscópica - de elementos fúngicos en materiales clinicos, donde su presencia es escasa o no fácilmente detectable por las técnicas tradicionales.

Se colocó una gota de la solución de blanco de Calcofluor con una gota de $\mathrm{KOH}$ al 20\%, sobre el material estudiado, examinándolo microscópicamente con luz U.V.

Los elementos fúngicos presentaron una fluorescencia verde manzana, lo que facilitó su detección en micosis sistémicas y subcutáneas. Presenta una sensibilidad similar a la coloración de Gomori-Grocott, pero tiene la ventaja de ser mucho más simple.

Se concluye que esta técnica es mucho más sensible y especifica que la observación microscópica directa.

\section{INTRODUCTION}

The increase in incidence of mycotic diseases in inmunosuppressed patients in these years has led to the search for fast, sensitive and specific diagnostic methods, in order to obtain an immediate appropriate therapy. This is why direct microscopic studies, basically those using fluorescence techniques, have acquired a great significance (Jones, 1990; Negroni, 1994; Ponton, 1994).

In a previous work (Ramos et al., 1990) we used "BA Blancophor" (fluorchrome) in parallel with $20 \% \mathrm{KOH}$ direct exams in skin, hair and nail materials, finding out that the detected percentage of positive specimens was sintifar to that with "BA: Blancophor". We also found out that with

\section{SUMMARY}

This microscopic observation technique makes it easy the identification of fungal elements in clinic materials wherein their presence is scarce or is not easily detectable by traditional techniques.

A drop of Calcofluor white solution plus a drop of $20 \% \mathrm{KOH}$ solution was poured on the material to be studied. It was microscopically examined under U.V. light.

The colour of the fungal elements presented an apple green coloured fluorescence.

This property of emitting fluorescence, allowed us the detection of a greater number of fungal elements causing subcutaneous as well as systemic mycoses.

It has the advantage of being a much more sensitive and specific method than direct microcopic observation, of having a similar sensitivity to GomoriGrocott dye, and being a faster and simpler technique than dyeing with silver methenamine.

this dye, a greater number of fungal elements (filaments, yeasts, and arthroconidia) were observed and that the morphologic characteristics were better visualised. It was thus demonstrated how practical it is the use of fluorescence microscopy as a quick easy method for the detections of fungi causing superficial mycoses.

Rüchel et al.(1993), has also adopted the fluorescence technique for the detection of fungi in skin and nail scrapings, non-sectioned biopsies and respiratory secretions.

Our aim is to use Calcofluor white (Heage et al., 1994) for the diagnosis of both systemic and subcutaneous 
mycoses in human materials as well as in animals inoculated in parallel with traditional coloration. This fluorchrome has also been used for micromorphologic observation of cultures (Darken, 1992).

\section{MATERIALS AND METHODS}

Samples: Thirty pieces of material belonging to carrying patients with probable systemic or subcutaneous mycoses who attended CEREMIC were processed. They included: cerebrospinal fluids. biopsies, broncho-alveolar lavages. ulcer secretions and puncture fluids.

Fifty Rockland white mice, weighing between 18 and $20 \mathrm{~g}$ were inoculated in their plantar calluses with suspensions in physiological solution containing either $10^{5}$ conidia or yeast-like cells per $\mathrm{ml}$ plus $0,1 \mathrm{ml}$ suspension of the following fungal species: Phialophora verrucosa, Exophiala (Wangiella) dermatitidis and Coccidioides immitis. Besides 5 guinea pigs were inoculated through their testicles with Paracoccidioides brasiliensis and 5 mice with Histoplasma capsulatum through their peritoneum. All the experimental protocols were performed according to the "Guide for the Care and Use of Laboratory Animals" (National Institutes of Health publication 80-23, revised 1978).

Microcultures were performed on the 5 strains under study for the observation of the fungal species.

Coloration techniques: The fluorchrome solution was prepared with 0.1g Calcofluor white (Sigma) and $0.05 \mathrm{~g}$ Evans blue (Sigma) in 100ml distilled water. This solution remains stable for a year in a caramel-coloured flask at room temperature

Two or three drops of the fluorchrome solution and one drop of $20 \% \mathrm{KOH}$ solution were placed on a slide. The material to be examined was placed on the drops, then covered with another slide and observed in the microscope with a fluorescence system (mercury lamp, specific objectives and the proper filters to work with an about 390$420 \mathrm{~nm}$ wavelength).

Also, direct exams were performed with $20 \% \mathrm{KOH}$ and lactophenol blue as well as with colorations such as Gram Nicolle, Giemsa and Gomori Groccott on all the materials under study.

\section{RESULTS}

In the 55 direct exams of the materials previously mentioned we observed: filaments in 7 of them; yeasts in 32: budding yeasts in 15: multi-budding yeasts in 7 : sclerotic cells in 5; spherules of Coccidiodes immitis in 5 . (Fig. 1, 2, 3, 4. 5). All these fungal elements presented an apple green coloured fluorescence.
Only in 43 of the 55 observations performed in parallel with $20 \% \mathrm{KOH}$ and lactophenol blue colouring matter we were able to distinguish the mentioned fungal element clearly.

With respect to Gram-Nicolle, Giemsa and Gomori Grocott colorations, the observations were the following: of the 55 studied extensions, the same fungal elements tinted with Gram-Nicolle technique could be seen in 45; of them, there was a coincidence in the observations of 46 preparations with Giemsa technique: whereas the 55 observations- which means all of them-were correctly seen with Gomori-Grocott coloration.

Calcofluor white was also useful to observe the elements that characterize micromorphologically these fungi in cultures, such as filaments, arthroconidia, macroconidia and conidiophore. (Fig. 6, 7, 8).

\section{DISCUSSION}

The detection of fungi that cause subcutaneous as well as systemic mycoses using direct microscopy with the clinical materials depends, mostly, on the morphologic and chemical characteristic of the fungus.

One of the greatest problems with direct microscopy, in daily laboratory practice, is the correct identification of infective organisms. This is why we have found that the technique with Calcofluor white is much better for the observation of fungal elements in materials where their presence is scarce and not easily detectable by traditional techniques. It is also important to ensure this stage of the analysis, especially with those fungi that are difficult to develop in the cultures normally used.

The Calcofluor white technique is based, on one hand, on the property of to radiate some chemical fluorescent substances when they are activated by U.V. light, and, on the other hand, on the affinity that these substances have with cellulose and chitin,which are the habitual components of the fungal cell wall.

It is an accepted fact that it is more effective than observation with $\mathrm{KOH}$ in direct exams for the diagnosis of fungal corneal ulcers, since both procedures were evaluated in parallel, finding greater positivity in the fluorchrome observations with respect to those performed with $\mathrm{KOH}$ alone (Chander et al., 1993).

The most widely used technique for direct microscopy is screening in $\mathrm{KOH}$ wet mounting. This procedure is very time-consuming and often fails because of the artifacts produced by the action of $\mathrm{KOH}$ on proteinaceous materials, the lack of contrast between the fungi, cellular debris and paucity of fungi in smears in certain cases (Arf-fa, 1985).

Calcofluor white stain has eliminated all these 

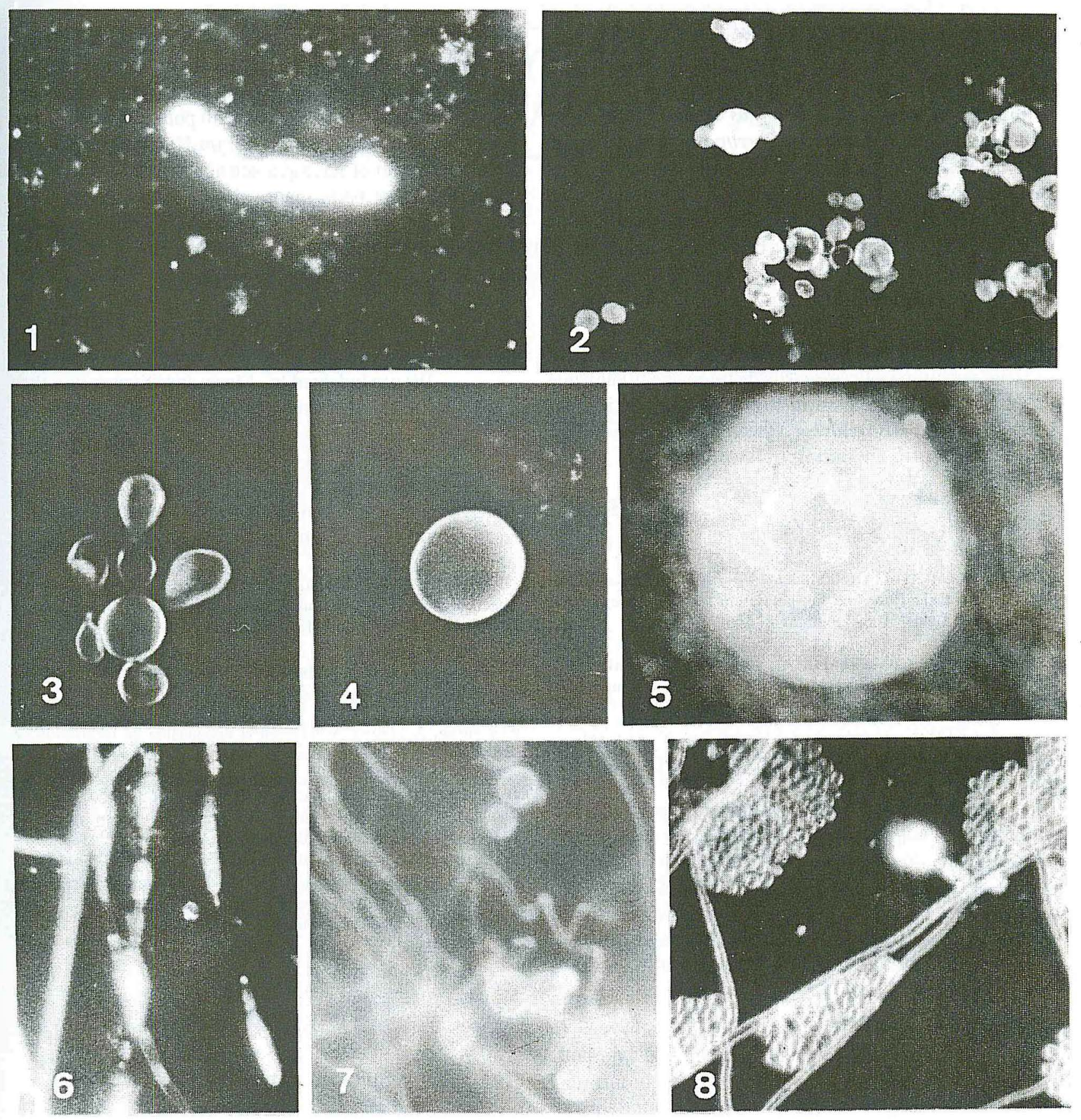

Fig. $\mathrm{N}^{\circ}$ 1- Wangiella dermatitides (Exophiala) with secretion in rat plantar callus with Calcofluor $\times 450$. Fig $\mathrm{N}^{\circ} 2$ Budding yeasts in sputum with Calcofluor $\times 450$. Fig $\mathrm{N}^{\circ}$ 3-Multi-budding yeasts of Paracoccidiodes brasiliensis in rat, testicular secretion with Calcofluor $\times 450$. Fig. $\mathbb{N}^{\circ}$ 4-Phialophora verrucosa sclerotial cells in secretion in rat plantar callus with Calcofluor. $x+50$. Fig. $\mathbb{N}^{\circ} \mathbf{5}$-Coccidioides immitis spherules in secretion in rat plantal callus with Calcofluor $\mathrm{x} 450$. Fig. $\mathrm{N}^{\circ} 6$-Coccidioides immitis filaments and arthroconidias in agar medium Saboraud glucosa with Calcofluor $\mathrm{x} 450$. Fig. $\mathrm{N}^{\circ} 7$-Histoplasma capsulatum macroconidia in agar medium Saboraud glucose with Calcofluor $\mathrm{x} 450$. Fig. $\mathrm{N}^{\circ}$ 8- Phialophora verrucosa conidiophores in agar Sabouraud glucose with Calcofluor $\times 450$. 
difficulties. Moreover, a specimen stained with Calcofluor white can be examined immediatly; in contrast $\mathrm{KOH}$ may take 18-24 h for complete digestion (Monheit et al., 1984).

As it may be observed in the pictures, arthroconidia of the Coccidioides immmitis, and the phialides neck of Phialophora verrucosa, present certain regions of greater fluorescence intensity due to the fact that they have more chitin and cellulose in their wall.

Unlike the opinion of other authors (Kwon-Chung et al., 1992) endospores may be clearly visualized in Coccidioides immitis spherules.

It is important to remark that, although the Cryptococcus neoformans capsule is not colored by this fluorchrome, yeast is. In sclerotial cells, neither longitudinal cells nor partition walls are easily distinguished. The same happens with tubercles and digitiform projections of macroconidia of Histoplasma capsulatum because of their mucopolysaccharide nature.

The disadvantage of this technique lies in the fact that it needs a fluorescence microscope, which is very expensive. But it has the advantage of being a much more sensitive method than direct observation with potassium hydroxide, lactophenol blue coloration, Gram-Nicolle and Giemsa colorations and of having a sensitivity similar to that of Gomori-Groccot, being in turn more economic, simpler and faster than coloration with silver methenamine and much more reliable for non-experienced observers. Besides, it may also be used for didactic purposes.

\section{ACKNOWLEDGEMENTS}

We are indebted to Maria José Svetaz for they cxpert technical assistance in obtaining the microphotographs.

\section{REFERENCES}

1.- Arffa, R.C.; Avni, Y.; Ishibashi, Y.; Robin, J. ; Kaufman, H.E. (1985). Calcofluor and ink-potassium hidroxide preparation for identifind fungi. Am.J.Ophthalmol.100:719-723

2.- Chander, J.; Chakrabarti, A.; Sharma, A.; Saini, J.S. ; Panigarhi, D. (1993). Evaluation of Calcofuor staining in the diagnosis of fungal cormeal ulcer. Mycoses 36:243-245

3.- Darken, M. (1962). Absorption and transport of fluorescent brightners by micoorganisms. Appl. Microbiol. 10:387-393

4.- Hageage, G.J. \& Harrington, D.J. (1994). Use of Calcofluor white in clinical mycology. Lab. Med.15:109-115

5.- Jones, J.M. (1990). Laboratory diagnosis of invasive Candidiasis.Clin. Microbiol.Rev. 3:32-45

6.- Kwon-Chung, K.J. \& Bennett J.E. (1992). Medical mycology. p48 Ed. Lea and Febiger Philadelphia- London.
7.- Monheit, J.E.; Cowan, D.F. \& Moore, D.G. (1984). Rapid detection of fungi in tissues using Calcofluor white and fluorescence microscopy. Arch, Pathol: Lab. Med.108:616-618

8.- Negroni, R. (1994). Avances en el diagnostico de laboratorio de las micosis profundas. Rev. Arg. Micologia 17: 3-13

9.- Ponton, J. (1996). Avances en el diagnóstico de laboratorio de la Candidiasis sistémica. Rev. Iberoam. Micol. 13:16-19

10.- Ramos, L.; Riccomi, A. \& Bracalenti, B.C. (1990). Uso del Blancophor (Fluorocromo) en la búsqueda de hongos en materiales de piel por microscopia directa. Rev. Iberoam. Micol. 7:107-110

11.- Rüchel, R. \& Margraf, S. (1993). Rapid microscopical diagnosis of deep-seated mycoses following of fresh specimens and staining with optical brighteners. Mycoses. 36:239-242 